\title{
Genotype X Trait Bi-Plot Analysis for Assessing Character Association in Cowpea (Vigna unguiculata L. Walp)
}

\author{
I. Adedeji $1^{*}$, A. T. Ajayi ${ }^{1}$, O.S. Osekita ${ }^{1}$ and K. L. Ogunruku ${ }^{1}$ \\ ${ }^{\mathrm{T}}$ Department of Plant Science and Biotechnology, Faculty of Science, Adekunle Ajasin University, Akungba Akoko, \\ Ondo State, Nigeria
}

*Corresponding Author

I. Adedeji

\section{Article History}

Received: 08.02.2020

Accepted: 17.02 .2020

Published: 29.02.2020

\begin{abstract}
Nigeria's restricted data on trait associations in cowpea genotypes has required setting up a study in this region to better understand the interactions between cowpea characteristics. The objectives of this study were therefore to assess the level of genetic variability and inter-character association among accessions of cowpea. Eight selected accessions from IITA were evaluated in the field in a Randomized Completely Block Design (RCBD) with three replications between September and December, 2018. Each replicate comprised eight accessions in plots of $5 \mathrm{~m}$ x $1 \mathrm{~m}$ dimension each; accessions were sown at $30 \mathrm{~cm}$ intra and $50 \mathrm{~cm}$ inter row spacing with $1 \mathrm{~m}$ separation between the accessions. Sixteen (16) quantitative traits were evaluated using five plants per accession per replicate. Significant differences were observed among accessions for most studied traits. Phenotypic variance was higher than genotypic variance for traits evaluated. High broad sense heritability and genetic advance as percent of mean were observed for emergence percentage, seeds per pod, seed weight; the seeds per plant had positive correlation with pod per plant and seed yield, indicating that selection for these will result in increase in yield. PCs 1 and 2 (with eigen value >1) accounted for more than $75.63 \%$ of the total variations among accessions. Different patterns of associations and genotype (accession) by trait interactions were observed. The genotype $\mathrm{x}$ trait bi-plots consistently indicated that seed yield had positive associations with most of the traits; especially peduncles per plant, seeds per plant, terminal leaflet length and terminal leaflet width.
\end{abstract}

Keywords: Genotype $\mathrm{x}$ trait bi-plot, Cowpea, genetic variability, heritability, correlation, Principal Component Analysis (PCA).

\section{INTRODUCTION}

Cowpea is an indispensable legume in Africa; it has a broad distribution in the tropics [23] in Africa, Central and South America and Asia [21]. Africa produces around 5.2 million tons of dried cowpea globally, with Nigeria as the largest producer and consumer accounting for 61 percent of Africa's production and 58 percent of its total production worldwide [20]. It is one of the most valuable dried food and legume crops in a semi-arid tropic with high socioeconomic, cultural and nutritious value because of its tolerance to drought and ability to grow on poor quality soils [8, 17]. Despite cowpeas ' nutritional and economic importance, the yield potential has still not been fully exploited and farmers are confronted with the problem of selecting the best variety of breeds for breeding program. Selection is an integral part of the breeding system, through which high productive genotypes are selected in a given environment. The complex nature of this function makes choice difficult for high yields. The output per unit area is the end product of components with several characters contributing to the output (reference).

Knowledge on the type and extent variation of the existing plant material and the interaction between the different characters are necessary for improving the yield [25]. Therefore knowledge of genetic variation, inheritance and genetic advance is needed for a breeder to select the best genotypes of cowpea for improvement. The assessment of genetic parameters reveals how relative the various types of genetic effects influence a difference in a plant's overall

Copyright @ 2020: This is an open-access article distributed under the terms of the Creative Commons Attribution license which permits unrestricted use, distribution, and reproduction in any medium for non commercial use (NonCommercial, or CC-BY-NC) provided the original author and source are credited. 
character. Genotypic and phenotypic coefficient of variation and heritability accompanied with genetic advance are very significant criteria for the refinement of characteristics.

Multivariate analyses are used for multiple interdependent measurements made on several individuals within similar environments and are effective tools for this purpose. Some breeders utilize multiple techniques for collecting genetic diversity knowledge for plant species leading to sufficiently comparable techniques with the best method for choosing some variants and illustrating the relative position of genotype included in such tests [30]. The Principal component analysis is very useful in analyzing the relative contribution of individual characteristics as an indicator for multivariate approaches [25]. This method describes a smaller number of variables which make up much of the overall variance. The simple correlation analysis describes the relation between two variables. Several approaches have been used to explain trait relations of different plants and the overall genotype profile.

A bi-plot of genotype by trait (GT), which is an implementation of the GGE bi-plot technique, has recently become an effective tool for multi-trait information exploration [27]. It is distinguished by the multivariate methodologies, since it evaluates genotypes based on several characteristics and identifies those that are superior with the desired variables which can be employed in breeding program as parent or even as commercial cultivars [18]. The GT bi plot analysis makes it possible to understand the genetic association between traits [28] which helps to analyze genotype by trait relationships [15]. It also provides information regarding the usefulness of genotypes in production, helps to detect features that are less important (redundant) and identifies those suitable for indirect selection of a target trait [6].The objective of this study was to estimate the level of genetic variability among eight accessions of cowpea and to assess the inter character association among traits using genotype $\mathrm{x}$ trait bi-plot analysis which may be used for cowpea improvement program.

\section{Materials ANd Methods Planting materials}

A total of eight (8) cowpea accessions used for this research were collected from the Department of Plant Science and Biotechnology, Adekunle Ajasin University, Akungba-Akoko Ondo State. (Table 1)

\section{Study location and Experimental design}

The research was conducted -between September and December, 2018 at the Experimental Field of the Department of Plant Science and Biotechnology, Adekunle Ajasin University, Akungba-Akoko (Latitude $7^{0} 37^{1} \mathrm{~N}$ and Longitude $5^{0} 44^{1} \mathrm{~N}$, Altitude 336 - $339 \mathrm{M}$ above sea level) Ondo State, Nigeria. The eight accessions used in this research were evaluated in the field in a Randomized Complete Block Design (RCBD) with three replications. Each accession was regarded as a treatment by planting units in rows with each treatment consisting of 20 plants totaling 480 plants in the field of a spacing of 50 by $30 \mathrm{~cm}$ and $1 \mathrm{~m}$ between treatments. Weeding was done as and when necessary.

\section{Data Collection and Analysis}

Data on emergence percentage (10 days after planting), morphological and agronomical characters (at five weeks after planting and at maturity respectively) were collected from 5 randomly selected plants and their means were recorded for all observations. Data for all variables measured were subjected to analysis of variance (ANOVA) to estimate the level of variability among the cowpea accessions, using SPSS Windows Version 20 (SPSS, Inc., Chicago IL). For each evaluated trait the phenotypic variation was portioned into genetic and non-genetic factors and estimated by the methods of Johnson et al. [13] and Uguru [24]:

$\mathrm{Vp}=\mathrm{MSg} / \mathrm{r} \ldots \ldots \ldots . .$. eq. 1

$\mathrm{Vg}=(\mathrm{MSg}-\mathrm{MSe}) / \mathrm{r}$...eq. 2

Where $\mathrm{Vp}$ and $\mathrm{Vg}$ are phenotypic variance and genotypic variance respectively; MSg, MSe and $\mathrm{r}$ were mean squares of accessions, mean square error and number of replications respectively. To compare the variations among traits, phenotypic coefficient of variation (PCV) and genotypic coefficient of variation (GCV) were computed according to the methods of Burton [7] and Allard [5]:

$\mathrm{PCV}=(\sqrt{ } \mathrm{Vp} / \mathrm{X}) 100 \ldots .$. eq. 3

$\mathrm{GCV}=(\sqrt{ } \mathrm{Vg} / \mathrm{X}) 100 \ldots .$. eq. 4

Where, VP, VG and $\mathrm{X}$ are phenotypic variance, genotypic variance and grand mean respectively for traits under consideration, and were classified according to [22].

as follows: $0-10 \%=$ low; $10-20 \%=$ moderate $; 20 \%=$ high . 
Broad sense heritability (H2B) was expressed as the percentage of the ratio of VG to VP as described by Allard et al. [5] as:

$\mathrm{h}^{2} \mathrm{~B}=\mathrm{Vg} / \mathrm{Vp} \mathrm{x} 100 \ldots \ldots \ldots \ldots \ldots \ldots$.......... 5 and was categorized according [20].

As follows: $0-30 \%=$ low $30-60 \%=$ moderate; $60 \%=$ high.

Genetic advances and Duncan multiple range tests were computed among all the measured traits. Correlation, principal component analysis and Bi-plot were done adopting Palaeontological Statistics Software Package for Education and Data Analysis (PAST) hammer et al.

Table-1: Names of the evaluated cowpea accessions

\begin{tabular}{|l|l|l|}
\hline S/N & CODES & ACCESSIONS \\
\hline 1 & A1 & IT98K-555-1 \\
\hline 2 & A2 & TVU-241 \\
\hline 3 & A3 & TVU-8660 \\
\hline 4 & A4 & TVU-224 \\
\hline 5 & A5 & TVU-11986 \\
\hline 6 & A6 & TVU-9256 \\
\hline 7 & A7 & TVU-9252 \\
\hline 8 & A8 & TVU-11979 \\
\hline
\end{tabular}

Table-2: Means performance and standard error of the observed quantitative traits of the eight (8) accessions of

\begin{tabular}{|c|c|c|c|c|c|c|c|c|}
\hline \multicolumn{9}{|c|}{ cowpea } \\
\hline TRT & EM & PH & NL & NMB & TLL & TLW & NODFF & PEDL \\
\hline IT98K-555-1 & $71.67 \pm 10.93^{b}$ & $17.43 \pm 2.07^{\mathrm{a}}$ & $1.01 \pm 4.67^{\mathrm{ab}}$ & $5.20 \pm 1.10^{\mathrm{a}}$ & $13.27 \pm 0.15^{\mathrm{a}}$ & $8.00 \pm 0.04^{\mathrm{ab}}$ & $41.67 \pm 0.24^{\mathrm{ab}}$ & $18.76 \pm 5.43^{\mathrm{a}}$ \\
\hline TVU-241 & $18.33 \pm 3.33^{\mathrm{a}}$ & $16.53 \pm 0.93^{\mathrm{a}}$ & $14.39 \pm 1.45^{\mathrm{ab}}$ & $3.93 \pm 0.58^{\mathrm{a}}$ & $11.30 \pm 2.15^{\mathrm{a}}$ & $7.96 \pm 1.52^{\mathrm{ab}}$ & $46.16 \pm 2.03^{b c}$ & $16.20 \pm 5.60^{\mathrm{a}}$ \\
\hline TVU-8660 & $20.00 \pm 7.64^{\mathrm{a}}$ & $16.51 \pm 2.06^{\mathrm{a}}$ & $24.67 \pm 1.92^{b}$ & $5.67 \pm 1.17^{\mathrm{a}}$ & $11.43 \pm 0.34^{\mathrm{a}}$ & $6.76 \pm 0.34^{\mathrm{a}}$ & $40.33 \pm 0.33^{\mathrm{a}}$ & $22.73 \pm 9.76^{\mathrm{a}}$ \\
\hline TVU-224 & $18.33 \pm 1.67^{\mathrm{a}}$ & $13.38 \pm 1.82^{\mathrm{a}}$ & $23.00 \pm 3.79^{\mathrm{ab}}$ & $5.00 \pm 0.58^{\mathrm{a}}$ & $11.08 \pm 0.30^{\mathrm{a}}$ & $8.24 \pm 0.34^{\mathrm{ab}}$ & $44.43 \pm 2.45^{\mathrm{abc}}$ & $19.90 \pm 7.92^{\mathrm{a}}$ \\
\hline TVU-11986 & $26.67 \pm 6.01^{\mathrm{a}}$ & $13.67 \pm 2.43^{\mathrm{a}}$ & $19.77 \pm 3.83^{\mathrm{ab}}$ & $4.97 \pm 0.89^{\mathrm{a}}$ & $11.19 \pm 0.36^{\mathrm{a}}$ & $7.63 \pm 0.17^{\mathrm{ab}}$ & $40.80 \pm 0.61^{\mathrm{a}}$ & $17.00 \pm 5.03^{\mathrm{a}}$ \\
\hline TVU-9256 & $26.67 \pm 1.67^{\mathrm{a}}$ & $17.36 \pm 1.16^{\mathrm{a}}$ & $23.11 \pm 1.57^{\mathrm{ab}}$ & $5.89 \pm 0.11^{\mathrm{a}}$ & $11.09 \pm 0.72^{\mathrm{a}}$ & $8.67 \pm 0.48^{\mathrm{ab}}$ & $43.20 \pm 2.56^{\mathrm{abc}}$ & $13.46 \pm 5.34^{\mathrm{a}}$ \\
\hline TVU-9252 & $10.00 \pm 2.89^{\mathrm{a}}$ & $15.67 \pm 1.59^{\mathrm{a}}$ & $17.73 \pm 4.71^{\mathrm{ab}}$ & $4.89 \pm 0.11^{\mathrm{a}}$ & $13.03 \pm 0.52^{\mathrm{a}}$ & $8.57 \pm 0.44^{\mathrm{ab}}$ & $46.87 \pm 0.69^{c}$ & $24.10 \pm 8.58^{a}$ \\
\hline TVU-11979 & $21.67 \pm 6.01^{\mathrm{a}}$ & $15.33 \pm 1.29^{\mathrm{a}}$ & $12.70 \pm 2.64^{\mathrm{a}}$ & $4.78 \pm 0.91^{\mathrm{a}}$ & $13.33 \pm 0.34^{\mathrm{a}}$ & $9.18 \pm 0.19^{b}$ & $47.70 \pm 0.45^{\mathrm{c}}$ & $17.83 \pm 6.40^{\mathrm{a}}$ \\
\hline
\end{tabular}

Means with similar superscript within a column are not significantly different from one another Using Duncan multiple Range Test at $\mathrm{P}=\leq 0.5$. EM=Emergence percentage, $\mathrm{PH}=\mathrm{Plant}$ height, $\mathrm{NL}=$ Number of leaves, $\mathrm{NMB}=\mathrm{Number}$ of main branches, TLL $=$ Terminal leaflet length, TLW $=$ Terminal leaflet width, NODFF $=$ Number of days to first flowering, PEDL=Peduncle length

Table-2: cont'd: Means performance and standard error of the observed quantitative traits of the eight (8) accessions cowpea

\begin{tabular}{|c|c|c|c|c|c|c|c|c|}
\hline TRT & PEDPL & PDPE & PDL & SPPD & SPDL & PDPL & SW & SYD \\
\hline IT98K-555-1 & $31.00 \pm 1.91^{\mathrm{b}}$ & $2.73 \pm 0.27^{\mathrm{a}}$ & $15.95 \pm 1.88^{\mathrm{a}}$ & $12.06 \pm 1.91^{\mathrm{ab}}$ & $74.93 \pm 10.75^{\mathrm{a}}$ & $6.13 \pm 0.17^{b}$ & $153.33 \pm 3.33^{\mathrm{d}}$ & $114.35 \pm 14.70^{\mathrm{abc}}$ \\
\hline TVU-241 & $15.23 \pm 2.58^{\mathrm{a}}$ & $2.10 \pm 0.10^{\mathrm{a}}$ & $19.63 \pm 1.78^{\mathrm{a}}$ & $15.43 \pm 0.80^{\mathrm{abc}}$ & $76.76 \pm 8.33^{\mathrm{a}}$ & $5.02 \pm 0.21^{\mathrm{ab}}$ & $163.33 \pm 6.67^{\mathrm{d}}$ & $126.28 \pm 17.75^{\mathrm{bc}}$ \\
\hline TVU-8660 & $22.73 \pm 4.40^{\mathrm{ab}}$ & $2.33 \pm 0.33^{\mathrm{a}}$ & $13.96 \pm 2.43^{\mathrm{a}}$ & $10.58 \pm 0.41^{\mathrm{abc}}$ & $39.83 \pm 7.58^{\mathrm{a}}$ & $3.42 \pm 0.30^{\mathrm{a}}$ & $153.33 \pm 8.82^{\mathrm{d}}$ & $62.33 \pm 15.60^{\mathrm{a}}$ \\
\hline TVU-224 & $16.00 \pm 2.27^{\mathrm{a}}$ & $2.53 \pm 0.30^{\mathrm{a}}$ & $17.36 \pm 0.14^{\mathrm{a}}$ & $17.22 \pm 1.56^{\mathrm{abc}}$ & $70.22 \pm 7.42^{\mathrm{a}}$ & $4.10 \pm 0.49^{\mathrm{ab}}$ & $126.67 \pm 6.67^{\mathrm{c}}$ & $89.27 \pm 11.53^{\mathrm{ab}}$ \\
\hline TVU-11986 & $20.50 \pm 5.22^{\mathrm{ab}}$ & $3.00 \pm 0.57^{\mathrm{a}}$ & $16.47 \pm 1.24^{\mathrm{a}}$ & $14.46 \pm 2.12^{\mathrm{abc}}$ & $76.13 \pm 20.70^{\mathrm{a}}$ & $3.46 \pm 1.10^{\mathrm{ab}}$ & $83.33 \pm 3.33^{\mathrm{a}}$ & $62.14 \pm 15.40^{\mathrm{a}}$ \\
\hline TVU-9256 & $12.53 \pm 3.87^{\mathrm{a}}$ & $2.73 \pm 0.13^{\mathrm{a}}$ & $16.30 \pm 3.57^{\mathrm{a}}$ & $13.53 \pm 2.62^{\mathrm{abc}}$ & $66.55 \pm 20.55^{\mathrm{a}}$ & $4.53 \pm 0.86^{\mathrm{ab}}$ & $146.67 \pm 3.33^{\mathrm{d}}$ & $98.94 \pm 31.69^{\mathrm{ab}}$ \\
\hline TVU-9252 & $16.60 \pm 4.55^{\mathrm{a}}$ & $2.67 \pm 0.33^{\mathrm{a}}$ & $16.50 \pm 0.50^{\mathrm{a}}$ & $13.93 \pm 1.73^{\mathrm{abc}}$ & $59.33 \pm 8.96^{\mathrm{a}}$ & $4.20 \pm 0.20^{\mathrm{ab}}$ & $93.33 \pm 8.82^{\mathrm{ab}}$ & $55.26 \pm 9.50^{\mathrm{a}}$ \\
\hline TVU-11979 & $20.00 \pm 4.80^{\mathrm{ab}}$ & $2.60 \pm 0.20^{\mathrm{a}}$ & $17.76 \pm 0.58^{\mathrm{a}}$ & $18.83 \pm 0.92^{\mathrm{abc}}$ & $160.50 \pm 17.45^{b}$ & $8.55 \pm 1.50^{c}$ & $106.67 \pm 3.33^{\mathrm{b}}$ & $171.67 \pm 15.40^{\mathrm{c}}$ \\
\hline
\end{tabular}

Means with similar superscript within a column are not significantly different from one another Using Duncan multiple Range Test at $\mathrm{P}=\leq 0.5$. $\mathrm{PEDPL}=$ Peduncle per plant, $\mathrm{PDPE}=$ Pod per peduncle, $\mathrm{PDL}=\mathrm{Pod}$ length, $\mathrm{SPPD}=\mathrm{Seed}$ per pod, SDPL=Seed per plant, PDPL= Pod per plant $S W=$ Seed weight, $S Y D=$ Seed yield 
Table-3: Genotypic and phenotypic variance, genotypic and phenotypic coefficient of variation, heritability and genetic advance as per cent mean estimates of observed quantitative characters of cowpea

\begin{tabular}{|l|l|l|l|l|l|l|}
\hline TRAITS & GV & PV & GCV & PCV & $\mathbf{H}^{2} \mathbf{B}$ & GAM \\
\hline EM & 329.76 & 416.66 & 68.1 & 76.55 & 79.14 & 122.88 \\
\hline PH & 0.22 & 6.73 & 2.97 & 16.48 & 3.25 & 1.02 \\
\hline NL & 7.11 & 40.55 & 13.72 & 32.77 & 17.54 & 11.43 \\
\hline NMB & -0.04 & 1.14 & -3.97 & 21.18 & -3.5 & 1.19 \\
\hline TLL & 0.38 & 2.50 & 5.15 & 13.22 & 15.17 & 4.01 \\
\hline TLW & 0.12 & 1.26 & 4.27 & 13.91 & 9.45 & 2.59 \\
\hline NODFF & 6.40 & 10.88 & 5.76 & 7.52 & 58.84 & 8.95 \\
\hline PEDL & 7.15 & 22.2 & 14.27 & 25.15 & 32.21 & 16.54 \\
\hline PEDPL & 17.24 & 64.02 & 21.45 & 41.35 & 26.92 & 22.12 \\
\hline PDPE & -0.03 & 0.27 & -6.69 & 20.08 & -11.11 & -4.63 \\
\hline PDL & 1.10 & 5.68 & 6.24 & 14.26 & 19.32 & 5.56 \\
\hline SPPD & 6.05 & 9.14 & 16.96 & 20.85 & 66.19 & 28.28 \\
\hline SPDL & 91.61 & 295.6 & 12.26 & 22.03 & 30.99 & 14.07 \\
\hline PDPL & 1.91 & 3.88 & 26.75 & 38.13 & 49.23 & 38.14 \\
\hline SW & 894.64 & 1010.71 & 23.31 & 24.77 & 88.52 & 44.89 \\
\hline SYD & 1253 & 2188.44 & 36.29 & 47.96 & 57.26 & 56.31 \\
\hline
\end{tabular}

$\mathrm{EM}=$ Emergence percentage, $\mathrm{PH}=$ Plant height, $\mathrm{NL}=$ Number of leaves, $\mathrm{NMB}=$ Number of main branches, TLL $=$ Terminal leaflet length, TLW $=$ Terminal leaflet width, NODFF $=$ Number of days to first flowering, PEDL $=$ Peduncle length, $\mathrm{PEDPL}=$ Peduncle per plant, $\mathrm{PDPE}=$ Pod per peduncle, $\mathrm{PDL}=$ Pod length, $\mathrm{SPPD}=\mathrm{Seed}$ per pod, $\mathrm{SDPL}=$ Seed per plant, $\mathrm{PDPL}=$ Pod per plant $\mathrm{SW}=$ Seed weight, $\mathrm{SYD}=$ Seed yield.

Table-4: Correlation coefficient among fifteen quantitative traits of eight accessions of cowpea

\begin{tabular}{|c|c|c|c|c|c|c|c|c|c|c|c|c|c|c|c|c|}
\hline & $\begin{array}{l}\mathbf{E} \\
\mathbf{M} \\
\end{array}$ & PH & NL & $\begin{array}{l}\text { NM } \\
\text { B } \\
\end{array}$ & $\begin{array}{l}\text { TL } \\
\text { L }\end{array}$ & $\begin{array}{l}\text { TL } \\
\text { W }\end{array}$ & $\begin{array}{l}\text { NODF } \\
\text { F }\end{array}$ & $\begin{array}{l}\text { PED } \\
\text { L }\end{array}$ & $\begin{array}{l}\text { PEDP } \\
\text { L }\end{array}$ & $\begin{array}{l}\text { PDP } \\
\text { E }\end{array}$ & PDL & $\begin{array}{l}\text { SPP } \\
\text { D }\end{array}$ & $\begin{array}{l}\text { SPD } \\
\text { L }\end{array}$ & $\begin{array}{l}\text { PDP } \\
\text { L }\end{array}$ & SW & SYD \\
\hline EM & 1 & $\begin{array}{l}0.4 \\
0\end{array}$ & $\begin{array}{l}- \\
0.01\end{array}$ & -0.08 & 0.26 & -0.07 & $\begin{array}{l}-0.26 \\
\end{array}$ & -0.07 & $0.48^{*}$ & 0.20 & -0.11 & $\begin{array}{l}-0.17 \\
\end{array}$ & 0.03 & 0.20 & 0.25 & 0.15 \\
\hline $\mathrm{PH}$ & & 1 & $\overline{-}-02$ & -0.04 & 0.32 & 0.31 & -0.27 & 0.16 & -0.03 & 0.10 & -0.20 & -0.12 & -0.01 & 0.03 & 0.30 & 0.11 \\
\hline NL & & & 1 & $0.69^{*}$ & $\begin{array}{l} \\
0.09\end{array}$ & -0.01 & $-0.47^{*}$ & 0.26 & 0.30 & 0.20 & $-0.42^{*}$ & $\overline{0}-46^{*}$ & $-0.46^{*}$ & -0.31 & 0.22 & -0.37 \\
\hline NMB & & & & 1 & 0.13 & 0.19 & $-0.43^{*}$ & $0.51^{*}$ & 0.09 & -0.06 & $-\overline{0.58^{* *}}$ & $0.46^{*}$ & -0.24 & -0.07 & 0.08 & -0.20 \\
\hline TLL & & & & & 1 & $0.64^{*}$ & -0.05 & 0.19 & 0.18 & 0.11 & -0.11 & 0.09 & 0.28 & 0.34 & $-\overline{0}$ & 0.17 \\
\hline TLW & & & & & & 1 & -0.01 & 0.22 & -0.13 & 0.26 & -0.07 & 0.17 & 0.25 & 0.25 & $\begin{array}{l}- \\
0.20\end{array}$ & 0.15 \\
\hline NODFF & & & & & & & 1 & -0.26 & -0.14 & -0.14 & $0.50^{*}$ & $0.57^{*}$ & $0.42^{*}$ & 0.24 & $\begin{array}{l}- \\
0.14\end{array}$ & 0.39 \\
\hline PEDL & & & & & & & & 1 & 0.22 & 0.12 & $-\overline{0.62^{* *}}$ & $\overline{0}-48^{*}$ & -0.26 & -0.08 & $\overline{-}-11$ & -0.31 \\
\hline PEDPL & & & & & & & & & 1 & $0.44^{*}$ & -0.24 & $0.41^{*}$ & -0.04 & 0.23 & 0.09 & -0.03 \\
\hline PDPE & & & & & & & & & & 1 & -0.04 & -0.22 & 0.10 & 0.30 & $\overline{0}-31$ & -0.09 \\
\hline PDL & & & & & & & & & & & 1 & $0.63^{*}$ & $0.44^{*}$ & 0.31 & 0.07 & $0.54^{*}$ \\
\hline SPPD & & & & & & & & & & & & 1 & $0.70^{3 *}$ & 0.37 & $\overline{-}-26$ & $0.60^{*}$ \\
\hline SPDL & & & & & & & & & & & & & 1 & $0.90^{* *}$ & $\overline{-}-23$ & $0.87^{*}$ \\
\hline $\begin{array}{l}\text { PDPL } \\
\end{array}$ & & & & & & & & & & & & & & 1 & $-\overline{0} 16$ & $0.80^{*}$ \\
\hline SW & & & & & & & & & & & & & & & 1 & 0.26 \\
\hline SYD & & & & & & & & & & & & & & & & 1 \\
\hline
\end{tabular}

$\mathrm{EM}=$ Emergence percentage, $\mathrm{PH}=$ Plant height, $\mathrm{NL}=$ Number of leaves, $\mathrm{NMB}=$ Number of main branches, $\mathrm{TLL}=$ Terminal leaflet length, TLW $=$ Terminal leaflet width, NODFF $=$ Number of days to first flowering, PEDL=Peduncle length, PEDPL= Peduncle per plant, $\mathrm{PDPE}=$ Pod per peduncle, $\mathrm{PDL}=$ Pod length, $\mathrm{SPPD}=\mathrm{Seed}$ per pod, $\mathrm{SDPL}=$ Seed per plant, $\mathrm{PDPL}=$ Pod per plant $\mathrm{SW}=$ Seed weight, $\mathrm{SYD}=$ Seed yield. 
Table-5: Principal Component Analysis based on quantitative characters of eight accessions of cowpea Principal Components

\begin{tabular}{|l|l|l|l|}
\hline & PC & PC2 & PC3 \\
\hline EIGEN VALUE & 5.69 & 3.20 & 2.45 \\
\hline CUMULATIVE EIGEN VALUE & 5.69 & 8.89 & 11.34 \\
\hline \% VARIABILITY & 37.95 & 21.31 & 16.37 \\
\hline CUMMULATIVE VARIABILITY & 37.95 & 59.26 & 75.63 \\
\hline VARIABLES & PC1 & PC2 & PC3 \\
\hline EMERGENCE PERCENTAGE & -0.08 & 0.48 & 0.02 \\
\hline PLANT HEIGHT & 0.07 & 0.35 & -0.34 \\
\hline NUMBER OF MAIN BRANCHES & -0.25 & 0.13 & 0.16 \\
\hline TERMINAL LEAF LENGTH & 0.16 & 0.36 & 0.25 \\
\hline TERMINAL LEAF WIDTH & 0.34 & 0.04 & 0.14 \\
\hline NUMBER OF DAYS TO FLOWERING & 0.36 & -0.11 & 0.04 \\
\hline PEDUNCLE LENGTH & -0.13 & 0.06 & 0.22 \\
\hline PEDUNCLE PER PLANT & -0.12 & 0.44 & 0.16 \\
\hline POD PER PEDUNCLE & 0.05 & 0.08 & 0.53 \\
\hline POD LENGTH & 0.33 & -0.15 & -0.23 \\
\hline SEED PER POD & 0.37 & -0.17 & 0.09 \\
\hline SEED PER PLANT & 0.37 & 0.15 & 0.14 \\
\hline POD PER PLANT & 0.33 & 0.33 & 0.03 \\
\hline SEED WEIGHT & 0.09 & 0.20 & -0.56 \\
\hline SEED YIELD & 0.34 & 0.25 & -0.17 \\
\hline & & & \\
\hline & & & \\
\hline & &
\end{tabular}

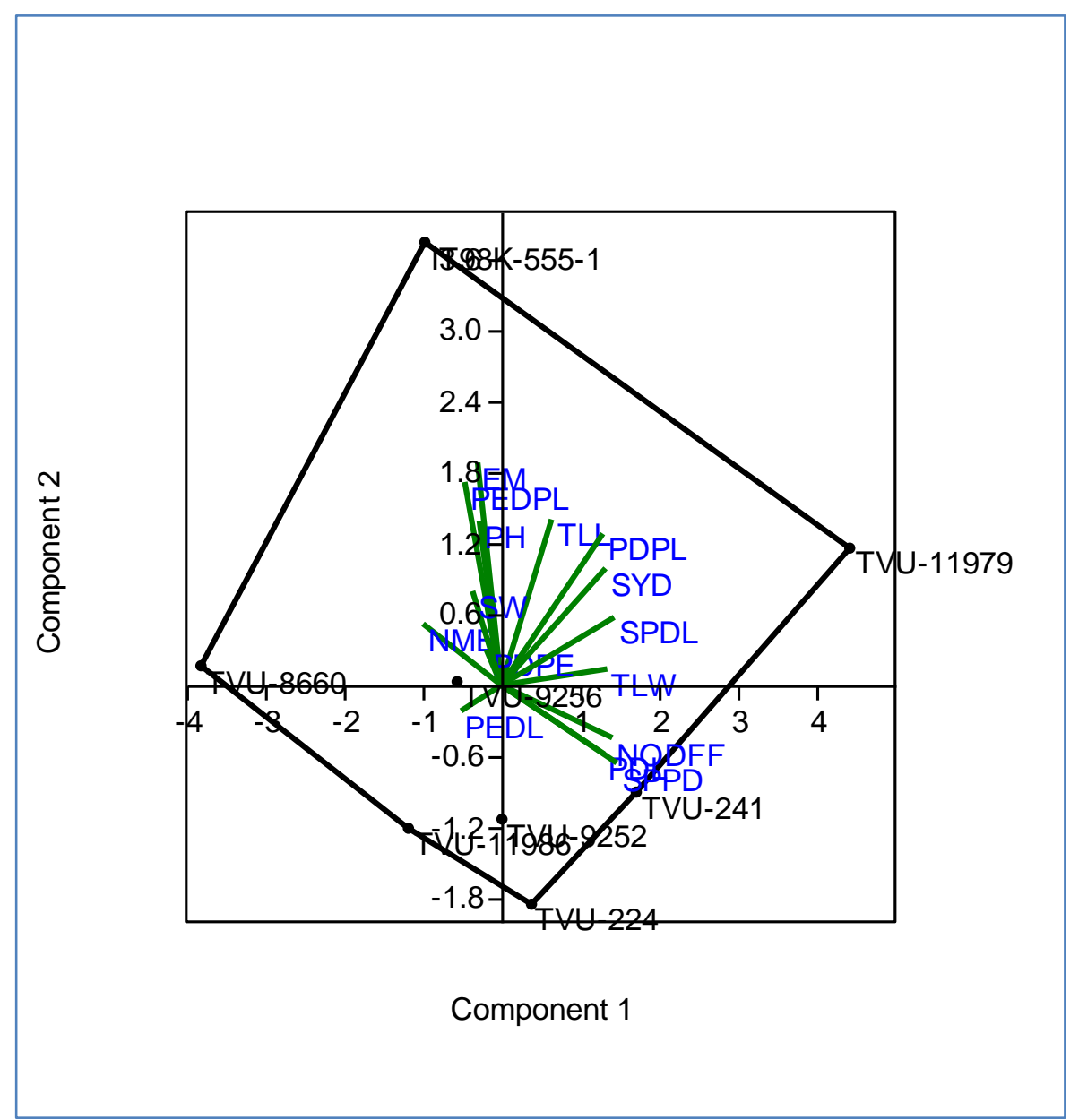

Fig-1: Biplot of principal component analysis showing inter character retionship among observed quantitative traits of eight accessions of cowpea 


\section{RESULTS AND DiSSCUSSION}

Analysis of variance and other genetic parameters help to formulate a suitable breeding parameter and being prerequisites for any effective method of crop improvement [19]. ANOVA showed that the mean squares for all traits were highly significant (Table 2) indicating the existence of high significant differences among the accessions. A wide range of significant variations were observed in emergence percentage (10\% to $71.7 \%$ ), plant height $(13.38 \mathrm{~cm}$ to 17.43 $\mathrm{cm}$ ), number of leaves per plant (12.70 to 23.11), and number of branches (3.93 to 5.89), number of peduncle per plant (15.23 to 31.00$)$, peduncle length $(16.20 \mathrm{~cm}$ to $24.10 \mathrm{~cm}$ ), number of days to flowering (40 days to 48 days), number of pods per peduncle ( 0 to 4$)$, number of pods per plant $(3.42$ to 8.55$)$, pod length $(13.9 \mathrm{~cm}$ to $19.63 \mathrm{~cm})$, terminal leaf length $(11 \mathrm{~cm}$ to $13.33 \mathrm{~cm})$, terminal width $(6.67 \mathrm{~cm}$ to $9.09 \mathrm{~cm})$ number of seeds per pod (10.58 to 18.83$)$, number of seeds per plant (39.83 to 160.50), seed yield (55.26 to 171.67) and 100-seed weight (83.30 g to $163.33 \mathrm{~g})$. These patterns of high variability were in conformity with the work done on cowpea by Adewale et al. [2] and Ajayi et al. [3].

Phenotypic variance was higher than genotypic variance in all the traits studied, similarly the phenotypic coefficients of variation (PCV) was higher than genotypic coefficient of variation (GCV) in all the traits studied (Table 3). This involves the combination of environmental and genetic factors. Similar results have been reported by other researchers in crops such as roselle and cowpea [12, 2, 1]. High genotypic and phenotypic coefficient of variance was obtained for emergence percentage $(68.10 \%)$, peduncles per plant $(21.45 \%)$, seed yield (36.29\%), pod per plant (26.75) and seed weight $(23.31 \mathrm{~kg})$. This implies the combination of environmental and genetic factors. Moderate genotypic coefficient of variation observed in number of leaves (13.72), peduncle length $(14.27 \mathrm{~cm})$ and seed per pod (16.96), seed per plant (12.26) showed the presence of moderate variability among the genetic stock studied [25]. While genotypic coefficient of variation observed in traits like plant height $(2.97 \mathrm{~cm})$, number of main branches $(-3.97)$, terminal leaflet length $(5.15 \mathrm{~cm})$, terminal leaflet width $(4.27 \mathrm{~cm})$, number of days to first flowering $(5.76)$, pods per plant $(-6.69)$, pod length $(6.24 \mathrm{~cm})$ show that these characters can be improved and enhanced by selection [25]. The closeness of phenotypic and genotypic coefficient of variation means that genetic and partial environmental factors controlled the characteristics studied. Through selection, in accordance with Fagwalawa [11] findings, the presence of greater magnitude of genetic variability in them can aid their improvement. In order to draw conclusions on the level of genetic variability, in addition to GCV values; heritability and genetic advance as per cent of mean estimates were computed.

Heritability values for the studied traits ranged from $-11.11 \%$ for number of pods per peduncle to $88.52 \%$ in seed weight (Table 3). High heritability estimate was recorded for seed weight $(88.52 \%)$, emergence percentage $(74.14 \%)$ seeds per pod $(66.19 \%)$, while moderate heritability was estimated for number of days to first flowering $(58.84 \%)$ and seed yield $(57.26 \%)$, pods per plant $(49.33 \%)$, peduncle length $(32.21 \%)$ and seeds per plant $(30.99 \%)$. High genetic advance as per cent of means was estimated for emergence percentage (122.88\%) seed yield (56.31\%), seed weight $(44.89 \%)$, pods per plant $(38.14 \%)$, seeds per pod $(28.28 \%)$ and peduncles per plant $(22.12 \%)$; moderate in peduncle length $(16.54 \%)$, seed per plant $(14.07 \%)$ and number of leaves (11.43). In almost all the characteristics studied, moderate to high heritability shows that the characteristics are less influenced by environmental effects, making them transmitted effectively to the progeny. For heritability estimates to be reliable, it must be accompanied by high genetic advance [12]. High estimates of heritability for emergence percentage, seed weight, seeds per pod coupled with their high genetic advance as percent of mean (GAM) indicate additive gene effects, and suggest that effective progress in improvement through selection could be achieved for yield. These results are in agreement with several workers on other crops $[16,25,12]$. Moderate heritability coupled with moderate genetic advance as percent of mean (GAM) observed in seed yield, pod per plant, seed per plant and peduncle length indicates that, by selecting these traits, a fair degree of improvement could be achieved [31,25]. Traits that showed low heritability and GAM, indicates that the traits are highly influenced by environmental effects, a condition which may make selection for them ineffective [12]. The correlation coefficient among measured revealed emergence percentage to be positively correlated with Peduncles per plant (0.48). Plant height was positively correlated with terminal leaf length $(0.32)$, terminal leaf width $(0.31)$ and seed weight $(0.30)$. Number of leaves had a strong significant positive correlation with number of main branches $(0.68)$ and was found to be significant and negatively correlated to number of days to flowering (-0.47), pod length $(-0.42)$, seed per pod (-0.46), seed per plant (-0.46), pod per plant (-0.31) and seed yield (-0.37). Number of main branches was positively correlated to peduncle length (0.51) and negatively correlated to pod length (-0.58), seeds per pod (0.46) and number of days to flowering (-0.43). Terminal leaflet length was highly significant and positive correlated to terminal leaflet width (0.64) and pods per plant (0.34). Number of days to flowering showed positive correlation with seeds per pod (0.57), pod length $(0.50)$, seeds per plant (0.42) and seed yield (0.39). Peduncle length was found to be significant and negatively correlated with pod length $(-0.62)$ and seeds per pod (-0.48). Peduncle per plant was positively correlated with pods per plant $(0.44)$ but negatively correlated with seeds per pod (-0.41). Pod length was positive and highly correlated to seeds per pod (0.63), seed yield (0.54), pods per plant (0.51) and seeds per plant (0.44). Seeds per pod were highly significant and positively correlated to seeds per plant $(0.70)$, seed yield $(0.60)$ and pods per plant $(0.37)$. Seeds per plant showed positive correlation with pods per plant (0.90) and seed yield (0.87). Pods per plant had positive correlation with seed yield (0.80). Most of the traits were found to be highly correlated among the tested genotypes (Table 4). Correlation measures the intensity of association between traits in which selection for a trait results in progress for all traits that are 
positively correlated and retrogressive for traits that are negatively correlated [4]. The high significant genotypic and phenotypic correlations between number of days to flowering and pod length, seeds per pod, and seeds per plant and seed yield indicate that genotypes which flowered earlier produced more pods and seeds per plant. This agrees with the findings of Ajayi et al. [3]. The high positive genotypic and phenotypic correlations between numbers of pods per plant, number of seeds per pod, number of seeds per plant and seed weight indicates that selection for these will result in increase in yield. Based on phenotypic and genotypic association between yield and yield contributing traits, it is suggested that selection should be made for the characters, which are having positive significant association to improve the seed yield per plant in cowpea.

The Principal Component analysis, eigen values and percentage variability of eight accessions of cowpea based on quantitative traits are presented in Table 5. The information obtained from a Principal Component analysis helps breeders to identify phenotypic characteristics that contribute great genetic variation among genotypes to select potential parents to cross blocks for interest traits. Ten (10) principal component axes were extracted for all the evaluated characters out of which the first three with the eigen value greater than 1 accounted for $75.63 \%$ of the total variation. The first Principal Component axis accounted for $37.95 \%$ of the total variation. Characters such as terminal leaf width (0.34), number of days to flowering (0.36), seeds per pod (0.37), seed per plant (0.37), pod length (0.33), seed yield (0.34), and pod per plant $(0.33)$ had the highest loadings with positive contributions towards the entire variation. Characters that contributed more strongly to PC2, which accounted for $21.31 \%$ of the total variation, were dominated by traits such emergence percentage (0.48), plant height $(0.35)$, terminal leaf length $(0.36)$, peduncle per plant $(0.44)$, pod per plant $(0.33)$, seed weight $(0.20)$, seed yield $(0.25)$ with highest loadings and positive contributions. The third component axis accounted for $16.37 \%$ of the entire variation and included traits such as pods per plant $(0.53)$, terminal leaf length (0.25), and peduncle length (0.22) with high loadings and positive contributions. The existence of wider phenotypic variability among the cowpea genotypes studied was further explained by the PCA's bi-plot (Figure 1). The PCA bi-plot gives an overview of the similarities and differences between genotypes and the interrelationships between the measured variables. The genotype $\mathrm{x}$ trait (GT) bi-plot resulted in four different groups. Group 1 comprised one genotype (TVU11979) on the right side of the curvex hul. Group 2 comprised three genotypes (TVU-241, TVU-9252 and TVU-221). Group 3 consisted of one genotype (TVU-11986) and group four consisted of three genotypes (TVU-866, TVU-9286 and TVU-555).

The bi-plots identified the best accession (s) for specific trait or group of traits. Vertex accessions show higher values for the traits that fall within the same sector in the bi-plot [28]. Hence, in the first sector, TVU-1197 had the higher seed yield and pods per plant; TVU-241 and TVU-224 had the highest pod length and seeds per pod and latest in flowering; TVU-555 had the highest emergence percentage, peduncle per plant, plant height; TVU-8660 and TVU-9256 had the highest number of branches and TVU-9252 and TVU- 11986 had the longest peduncle length.

The GT bi-plot of mean performance of cowpea genotypes captured $59.30 \%$ of the total variation due to genotype and genotype by trait interactions. As previously reported by Yan and Rajcan [26]. This result reflects the complexity of the measured trait interrelationships. Nevertheless, the fundamental patterns among the traits could still be captured by the bi-plots [14]. The first two Principal Components (PC1 and PC2) explained 37.95\% and 21.31\%, respectively. The polygon view of the bi-plot helps identify genotypes with the highest values for one or more traits. The vertex genotypes in bi-plot can be characterized for specific attributes, while those near to origin of bi-plot can be considered as genotypes with a wide range of attributes. The vertex genotypes from these findings were TVU-11979, TVU-241, TVU-9252, TVU221, TVU 11986, TVU-866, TVU-9286 AND TVU-555. Vertex genotypes and their corresponding genotypes are suitable candidates for heterosis in hybrid development in different sections of the bi-plot [28]. These genotypes are the best or the poorest in some or all of the traits since they had the longest distance from the origin of bi-plot. In view of this bi-plot, TVU-11979 fell in the sector of traits such as terminal leaf length, pods per plant, seed yield, seeds per plant, terminal leaf width, pods per peduncle, suggesting that this genotype had the highest or near the highest for this traits. Similarly, TVU-241 and the other genotype in this sector had the highest value for the number of days to flowering, seeds per pod, and pod length. TVU-11986 had the highest value for peduncle length, whereas TVU-866, TVU-9286 AND TVU-555 were the highest in number of main branches, seed weight, and plant height, peduncles per plant and emergence percentage.

The vector angles in bi-plot represent the phenotypic correlation between attributes over all genotype values for each attribute. The cosine of angle between a pair of morphological traits vectors approximates correlation between them $[26,27]$. An acute angle $\left(<90^{\circ}\right)$ indicates a positive correlation; an angle close to 90 degrees indicate the traits are not correlated, whereas an obtuse angle close to 180 degrees represents a strong negative relationship. The distance on the trait vector to the point where a perpendicular line falls from the plotting point of the genotype to the vector is proportional to that attribute's model (predicted) value [9]. In the figure 1, a cosine of the angle between vectors approximates the correlation coefficient between any two elements. Since the angle cosine between the vectors of any two traits approximates the correlation coefficient between them, this view of bi-plot is best for visualizing the 
interrelationship among traits and it is shown that the trait vectors help investigate the interrelationship between traits [27]. This view of bi-plot suggests close associations among terminal leaf length, pod per plant, seed yield, seed per plant, terminal leaf width, and pod per plant. From the other sector of the bi-plot positive correlation was observed between number of days to flowering, seed per pod and pod length. There was positive association between number of main branches, seed weight, and plant height, peduncle per plant and emergence percentage. Emergence percentage had a positive association with peduncle per plant, plant height, seed weight, pod per plant and number of main branches. Seed yield showed positive correlation with, seeds per plant, pods per plant, terminal leaf length, and terminal leaflet width. Most of the measured traits were positively or negatively associated with seed yield. Only a few traits were apparently independent of seed yield, and these include number of days to flowering and pod length as indicated by their near $90^{\circ}$ angles with seed yield $(r=\cos 90=0)$. From the bi-plot, traits such as seeds per pod, peduncle length, number of main branches, seed weight and pod per plant were negatively associated with seed yield, as indicated by their near angle of approximately 180 degrees $(r=\cos 180=-1)$. Some discrepancies between the bi-plot predictions and original data were expected because the bi-plot accounted for $<100 \%$ of the total variation (about 59.3\%).

A vector is drawn from the bi-plot origin to each genotype marker in the GT bi-plot to help visualize associations between and among traits and genotypes. The results obtained from the GT bi-plot of the genotypes identified parameters that could be considered best in discriminating among the genotypes. A major advantage of GT biplot analysis is the provision of data which helps identify less important trait and those which can be selected indirectly for target characteristics such as seed yield [26]. GT bi-plot graphically displays the genotype by trait relationship and allows the visualization of the associations among traits across the genotypes and of the trait profile of the genotypes [27].

As observed from this study, it appeared possible to improve cowpea genotypes by selecting genotypes with higher seed yield, seeds per plant, and pods per plant, terminal leaf length, and terminal leaf width. Since these measures were highly correlated, there is no need to measure all of them. Any of these measures should be effective for indirect selection for seed yield. Pods per plant and seeds per plant were closely associated with seed yield and it is therefore recommended as a trait for indirect selection. This view of bi-plot can also be used to identify redundant traits in addition to revealing traits that can be used for indirect selection. Obviously, much money and working time could be saved without losing useful information by better understanding the interrelationships between different traits, i.e. by using biplots.

\section{CONCLUSION}

This study had revealed that there is sufficient genetic variability among the tested accessions and this can be exploited for use in cowpea improvement programme. The High estimates of GCV, heritability and genetic advance as percent of mean for seed yield indicate the possibility of improving this most important trait through selection. Results of the GT bi-plot analysis that captured $59.3 \%$ of the total variation indicated that selecting for seeds per plant, pods per plant, terminal leaf length, terminal leaf width and number of days to flowering, results in genotypes that produce high seed yield. In addition, this study demonstrated that the GT bi-plot is an excellent tool for visualizing genotype by trait data. First, it effectively revealed the interrelationships among the cowpea traits. Secondly, it provided a tool for visual comparison between genotypes based on multiple traits. Accession TVU-11979 proved to be the best accession compared to others due to its association with desirable seed yield characteristics. This accession is suggested for further breeding evaluation and recommended as a suitable parental line that can be crossed with accession TVU-241, TVU-224, TVU-9256, TVU-9252 and TVU- 11986 for seed yield improvement.

\section{REFERENCES}

1. Adeigbe, O. O., Adewale, B. D., \& Fawole, I. O. (2011). Genetic variability, stability and relationship among some cowpea (Vigna unguiculata L. walp) breeding lines. Journal of Plant Breeding and Crop Science, 3(9): 203 - 208.

2. Adewale, B. D., Okonji, C., Oyekanmi, A. A., Akintobi, D. A. C., \& Aremu, C. O. (2010). Genotypic variability and stability of some grain yield components of cowpea. African Journal of Agricultural Research, 5: 874 - 880.

3. Ajayi, A. T., Osekita, O. S., \& Osaghae, S. O. (2014). Variability among some accessions of cowpea (Vigna unguiculata L. Walp) in Nigeria based on the expression of quantitative traits. Futa Journal of Research in Science (in press).

4. Akinwale, M. G., Gregorio, G., Nwilene, F., Akinyele, B. O., Ogunbayo, S. A., \& Odiyi, A. C. Heritability and correlation coefficient analysis for yield and its components in rice (Oryza sativa L.). African Journal of Plant Science, 5(3): 207 - 212.

5. Allard, R. W. (1960). Principle of plant breeding, John Wiley and Sons, Inc., New York.

6. Badu-Apraku, B., \& Akinwale R. O. (2011). Cultivar evaluation and trait analysis of tropical early maturing maize under Striga and Striga-free environments. Field Crop Res. 121: 186-194.

7. Burton, G. W. (1952). Quantitative interaction in grasses. In: Proc. 6th Inter. Grassland Congr, 1: 277 - 283. 
8. Davis, D. W., Oelke, E. A., Oplinger, E.S., Doll, J. D., Hanson C.V., \& Putman, D.H. (1991). Alternative field crops manual: cowpea. University of Wisconsin-Extension, Cooperative Extension; and University of Minnesota, Center for Alternative Plant and Animal Products and the Minnesota Extension Service.

9. Delacy, I. H., Skovmand, B., \& Huerta, J. (2000). Characterization of Mexican wheat landraces using agronomically useful attributes. Gen Res Crop Evol., 47: 591-602

10. Denton, O. A., \& Nwangburuka, C. C. (2011). Heritability, genetic advance and character association in six related characters of Solanum anguivi. Asian Journal of Agricultural Research, 5: 201 - 207.

11. Fagwalawa, L. D. (2000). Agro-physiological characterization of some early, medium and late maturing varieties of cowpea under sole and intercropping systems. Ph.d. Thesis, Department of Biological Sciences, Bayero University, Kano.

12. Ibrahim, M. M., \& Hussein, R. M., (2006). Variability, heritability and genetic advance in some genotypes of Roselle (Hibiscus sabdariffa L.). World Journal of Agricultural Sciences, 2(3): 340 - 345.

13. Johnson, H.W., Robinson, H.F., \& Comstock, R.E. (1955). Estimates of genetic and environmental variability in soybean. Agronomy Journal, 47(7): 314 - 318.

14. Kroonenberg, P.M. (1995). Introduction to biplots for $\mathrm{G} \times \mathrm{E}$ tables. Department of Mathematics, research report 51, University of Queensland.

15. Lee, S. J., Yan, W., Joung, K. A., \& Ill M. C. (2003). Effects of year, site, genotype, and their interaction on the concentration of various isoflavones in soybean. Field Crop Res, 81: 181-192.

16. Munchi, A. D., \& Behera, T. K. (2000). Genetic variability, heritability and genetic advance for some traits in chillies (Capsicum annum L.). Vegetable Science, 27(1): $39-41$.

17. Musvosvi, C. (2009). Morphological characterisation and interrelationships among descriptors in some cowpea genotypes. Journal of African Crop Science, 9: 501-507.

18. Ober, E. S., Bloa, M. L., Clark, C. J. A., Royal, A. K., Jaggard, W., \& Pidgeon, K. W. (2005). Evaluation of physiological traits as indirect selection criteria for drought tolerance in sugar beet. Field Crop Res, 91: 231-249.

19. Osekita, O. S., \& Ajayi A. T. (2013). Character expression and selection differential for yield and its components in soybean (Glycine max L. Merrill). Academia Journal of Agricultural Research, 1(7): 167 - 171.

20. Robinson, H.F., Comstock, R.E., \& Harvey P.H. (1949). Estimates of heritability and degree of dominance in corn. Agronomy Journal, 42: 353 - 359.

21. Singh, S. S., Mohan Raj, D. R., Dashiell, K. E., \& Jackai, L.E.N. (1997). Advances in cowpea research. International Institute of Tropical Agriculture/Japan International Research Center for Agricultural Sciences, Hong Kong, 99-113.

22. Sivasubramanian, S., \& Menon, M. (1973). Heterosis and inbreeding depression in rice. Madras Agricultural Journal, 60: 11-39.

23. Uarrota, V. G. (2010). Response of cowpea (Vigna unguiculata L. Walp) to water stress and phosphorus fertilization. J. Agron. 9: $87-91$.

24. Uguru, M. I. (1995). Heritable relationships and variability of yield and yield components in vegetable cowpea. African Crop Science Journal, 3(1): 23-28.

25. Vijayan, S. (2005). Statistical analysis of influence of morphological characters on yield in selected vegetable crops. M.Sc. Thesis, Dharwad University of Agricultural Sciences, Dharwad.

26. Yan, W., \& Rajcan, I. (2002). Biplot evaluation of test sites and trait relations of soybean in Ontario. Crop Sci, 42: 11-20.

27. Yan, W. and Kang, M. S. (2003). GGE-biplot analysis: a graphical tool for breeders. Geneticists and agronomists. CRD Press, Boca Raton.

28. Yan, W., Kang, M. S., MA, B., Wood, S. S., \& Cornelius, P. L. (2007). GGE biplot vs. AMMI analysis of genotypeby-environment data. Crop Sci., 47(5): 643-655.

29. Yan, W., Tinker, N. A., Molnar, S., Mcelroy, A., \& Fregeau-Reid, J. (2007). Associations among oat traits and their responses to the environment in North America. J. Crop Improv. 20: 1-29.

30. Fayeun, L. S., \& Odiyi, A. C. (2015). Variation and heritability of marketable leaf yield components in fluted pumpkin. Scientia Agriculturae, 11, 8-14.

31. Amarchand, S., Rama Mohan, T. R., \& Ramakrishnan, P. (2000). A novel chemical solution technique for the preparation of nano size titanium powders from titanium dioxide. Advanced Powder Technology, 11(4), 415-422. 